\title{
ANALISIS MODEL PEER EDUCATION METODE ADOLESCENT FRIENDLY TERHADAP PENINGKATAN PENGETAHUAN DAN SIKAP REMAJA TENTANG PERILAKU SEKSUAL BERISIKO
}

\author{
Muhammad Hasbi ${ }^{1}$ \\ ${ }^{1}$ Jurusan Keperawatan/Poltekkes Kemenkes Mataram/ Indonesia
}

\begin{abstract}
Abstrak
Remaja mempunyai perilaku berisiko yang lebih tinggi dibandingkan dengan kelompok usia lain di masyarakat. Perilaku berisiko terhadap kesehatan remaja mencakup injury, rokok, alkohol dan obat -obatan, perilaku seksual, perilaku diet yang tidak sehat, dan tidak ada aktifitas fisik (Hitchcock,1999). Pelayanan kesehatan remaja di Indonesia diwujudkan dalam bentuk pelayanan kesehatan peduli remaja (PKPR) yang berada di setiap Puskesmas dengan tujuan untuk meningkatkan kesehatan reproduksi remaja (Depkes, 2003). Pendidikan kelompok sebaya (peer education) diyakini efektif digunakan sebagai pendekatan pada remaja karena sesuai dengan karakteristik kuatnya ikatan sebaya diantara mereka. Penelitian ini bertujuan untuk menganalisa pengaruh metode adolescent friendly terhadap peningkatan pengetahuan dan sikap remaja tentang perilaku seksual berisiko. Penelitian ini adalah penelitian kuasi eksperimen dengan pre-post test design. Populasi adalah remaja di Desa Jeringo dan Desa Penimbung Kecamatan Gunung Sari Lombok Barat. Sampel dipilih berdasarkan kriteria inklusi dan eksklusi kemudian dibagi menjadi dua kelompok kontrol (remaja Desa Penimbung) dan kelompok intervensi (remaja Desa Jeringo). Analisa data menggunakan paired $t$-test untuk menganalisa pengetahuan dan sikap responden sebelum dan sesudah intervensi pada masing-masing kelompok, dan analisa indpendent t-test untuk menganalisa perbedaan pengetahuan dan sikap responden antara kelompok intervensi dan kelompok kontrol. Hasil penelitian menunjukkan terdapat peningkatan rata-rata skor pengetahuan dan sikap yang bermakna antara sebelum dan sesudah diberikan intervensi pada kelompok intervensi ( $p$ value 0.000, alpha $=0.05$ ). Tidak terdapat peningkatan rata-rata skor pengetahuan dan sikap yang bermakna sebelum dan sesudah diberikan edukasi sebaya antara kelompok kontrol. Metode adolescent friendly (peer education) berpotensi meningkatkan pengetahuan dan sikap responden. Sehingga perlu dikembangkan dalam pelayanan kesehatan khususnya puskesmas untuk peningkatan kesehatan remaja di masyarakat.
\end{abstract}

Kata kunci: remaja, perilaku seksual berisiko, pendidikan sebaya, adolescent friendly 


\title{
ANALYSIS OF THE PEER EDUCATION MODEL OF ADOLESCENT FRIENDLY METHODS ON INCREASING ADOLESCENT KNOWLEDGE AND ATTITUDES ON RISKY SEXUAL BEHAVIOR
}

\begin{abstract}
Adolesccent have higher risk behavior compared to other age groups in the community. Risk behaviors for adolescent health include injury, cigarettes, alcohol and drugs, sexual behavior, unhealthy diet behavior and no physical activity (Hitchcock, 1999). Adolescent health services in Indonesia are manifested in the form of adolescent caring health services (PKPR) in each Puskesmas with the aim of improving adolescent reproductive health (MOH, 2003). Peer education is believed to be effective to be used as an approach to adolescents because it fits the characteristics of peer strength among them. This study aims to analyze the effect of adolescent friendly methods on increasing adolescent knowledge and attitudes about risky sexual behavior. This study was a quasi-experimental study with pre-post test design. The population is teenagers in Jeringo Village and Penimbung Village, Gunung Sari District, West Lombok. Samples selected based on inclusion and exclusion criteria were then divided into two control groups (Penimbung Village adolescents) and intervention groups (Jeringo Village adolescents). Data analysis using paired t-test to analyze the knowledge and attitudes of respondents before and after intervention in each group, and independent t-test analysis to analyze differences in knowledge and attitudes of respondents between the intervention group and the control group. The results showed an increase in the mean score of knowledge and attitudes that were significant between before and after intervention in the intervention group ( $\mathrm{p}$ value 0.000 , alpha $=0.05)$. There was no increase in the mean score of knowledge and attitudes that were significant before and after peer education was given between the control groups. Adolescent friendly method (peer education) has the potential to increase the knowledge and attitudes of respondents. So it needs to be developed in health services, especially health centers to improve the health of adolescents in the community.
\end{abstract}

\section{PENDAHULUAN}

Perilaku remaja saat ini sudah sangat mengkhawatirkan, hal ini ditandai dengan semakin meningkatnya kasus-kasus seperti aborsi, kehamilan tidak diinginkan (KTD), dan penyakit menular seksual (PMS) termasuk seksual berisiko/AIDS. Setiap bulannya kira-kira 15 juta remaja yang berusia 15-19 tahun melahirkan, 4 juta remaja melakukan aborsi dan hampir 100 juta terinfeksi Penyakit Menular Seksual (PMS) yang dapat disembuhkan terjadi pada remaja (Triswan, 2007).

Gaya hidup pada masa remaja biasanya mengakibatkan perilaku berisiko yang lebih tinggi dibandingkan dengan kelompok usia lain di masyarakat. Perilaku berisiko terhadap kesehatan remaja mencakup injury, rokok, alkohol dan obat -obatan, perilaku seksual, perilaku diet yang tidak sehat, dan tidak ada aktifitas fisik (Hitchcock,1999). Hasil penelitian Rachmawati. M dan Sandralina. M tahun 2015 tentang perilaku seksual remaja di provinsi Nusa Tenggara Barat (NTB) diperoleh data sebagai berikut remaja yang pernah berpegangan tangan adalah 86,1\%, pernah berciuman bibir 31,8\%, pernah meraba/merangsang $12,1 \%$, dan pernah melakukan hubungan seksual sebanyak $5 \%$. Berdasarkan karakteristik remaja, usia remaja paling banyak di rentang 15-19 tahunyaitusejumlah 64,7\%, 93,1\% pernahmendengartentang NAPZA, 90,1\% pernah mendengar tentang HIV AIDS, dan 56,9\% pernah mendengar IMS. 
Remaja sangat dipengaruhi oleh teman sebaya dalam berprilaku positif dan negatif. Penulis merasa tertarik untuk menerapkan metode adolescent friendly yang diberikan oleh teman sebaya melalui peer edukator dengan harapan dapat meningkatan pengetahuan dan silap remaja tentang seksual berisiko.

\section{METODE}

Penelitian ini adalah penelitian kuasi eksperimen dengan pre-post test design. Populasi penelitian adalah Populasi adalah remaja di Desa Jeringo dan Desa Penimbung Kecamatan Gunung Sari Lombok Barat. Sampel dipilih berdasarkan kriteria inklusi dan eksklusi kemudian dibagi menjadi dua kelompok kontrol (remaja Desa Penimbung) dan kelompok intervensi (remaja Desa Jeringo). Penghitungan besar sampel menggunakan cara rule of thumb yaitu pengambilan sampel minimal berdasarkan jumlah seluruh variabel independen. Angka yang disarankan ialah 10 kali lebih banyak dari jumlah variabel independen. 30 responden ditetapkan sebagai sampel.

Variabel independen adalah metode peer education model adolescent friendly dan variabel dependen adalah pengetahuan dan sikap responden tentang perilaku seksual berisiko. Analisa data menggunakan paired t-test untuk menganalisa pengetahuan dan sikap responden sebelum dan sesudah intervensi pada masing-masing kelompok, dan analisa indpendent t-test untuk menganalisa perbedaan pengetahuan dan sikap responden antara kelompok intervensi dan kelompok kontrol.

\section{HASIL PENELITIAN}

1. Karakteristik responden berdasarkan Usia, Jenis kelamin, Pendidikan, dan Keikutsertaan Dalam Organisasi

Tabel 1. Distribusi Responden Berdasarkan Usia, Jenis Kelamin, Pendidikan dan Keikutsertaan Dalam Organisasi Pada Kelompok Intervensi Dan Kontrol Di Desa Jeringo dan Desa Penimbung Kec. Gunung Sari Lombok Barat.

\begin{tabular}{|c|c|c|c|c|c|}
\hline \multirow{3}{*}{ Karakteristik } & \multicolumn{4}{|c|}{ Responden } & \multirow{3}{*}{$\frac{\text { Total }}{\mathrm{f}}$} \\
\hline & \multicolumn{2}{|c|}{$\begin{array}{c}\text { Intervensi } \\
\text { (Desa Jeringo) }\end{array}$} & \multicolumn{2}{|c|}{$\begin{array}{c}\text { Kontrol } \\
\text { (Desa Penimbung) }\end{array}$} & \\
\hline & $\mathrm{f}$ & $\%$ & $\mathrm{f}$ & $\%$ & \\
\hline \multicolumn{6}{|l|}{ Usia : } \\
\hline a. $<20$ & 11 & 37.7 & 25 & 83.3 & 36 \\
\hline b. $20-24$ & 19 & 63.3 & 5 & 17.7 & 24 \\
\hline Total & 30 & & 30 & & 60 \\
\hline \multicolumn{6}{|l|}{ Jenis Kelamin : } \\
\hline a. Laki- laki & 11 & 36.7 & 18 & 60.0 & 29 \\
\hline b. Perempuan & 19 & 63.3 & 12 & 40.0 & 31 \\
\hline Total & 30 & & 30 & & 60 \\
\hline \multicolumn{6}{|l|}{ Tingkat Pendidikan : } \\
\hline $\begin{array}{l}\text { b. SMP } \\
\text { b. SD }\end{array}$ & 1 & 3.3 & 3 & 10.0 & 4 \\
\hline c. SMA & 14 & 47.7 & 23 & 76.7 & 37 \\
\hline c. Perguruan Tinggi & 15 & 50.0 & 2 & 6.7 & 17 \\
\hline
\end{tabular}




\begin{tabular}{|c|c|c|c|c|c|}
\hline \multirow{2}{*}{$\begin{array}{l}\text { Total } \\
\text { Keikutsertaar } \\
\text { Organisasi }\end{array}$} & \multirow[t]{2}{*}{30} & \multicolumn{3}{|c|}{30} & \multirow[t]{2}{*}{60} \\
\hline & & & & & \\
\hline a. Ikut & 21 & 70.0 & 26 & 87.7 & 47 \\
\hline b. Tidak Ikut & 9 & 30.0 & 4 & 13.3 & 13 \\
\hline Total & 30 & & 30 & & 60 \\
\hline
\end{tabular}

Tabel 1 menunjukan bahwa distribusi proporsi usia responden pada kelompok intervensi dan kontrol tidak jauh berbeda. Proporsi usia terbanyak pada kelompok intervensi adalah antara usia 20 24 tahun sebanyak 19 orang (37.7\%), sedangkan pada kelompok kontrol proporsi usia terbanyak adalah usia kurang dari 20 tahun yaitu sebanyak 25 orang ( $83.3 \%$ ). Proporsi jenis kelamin responden terbanyak pada kelompok intervensi adalah perempuan yaitu sebanyak 19 orang (63.3\%), sedangkan pada kelompok kontrol terbanyak adalah jenis kelamin laki-laki yaitu sebanyak 18 orang $(60.0 \%)$.

Proporsi tingkat pendidikan responden terbanyak pada kelompok intervensi adalah Pendidikan Tinggi (PT) yaitu sebanyak 15 orang (50.0\%), diikuti pendidikan menengah sebanyak 14 orang $(47,7)$ terendah adalah SMP sebanyak 1 orang $(3.3 \%)$, sedangkan pada kelompok kontrol roporsi terbanyak adalah pendidikan SMA yaitu sebanyak 23 orang (76.7\%) dan tingkat pendidikan terendah adalah SD yaitu sebanyak 2 orang (6.70\%). Proporsi keikutsertaan dalam organisasi baik responden kelompok intervensi maupun kontrol sama yaitu sebagian besar mengikuti organisasi. Kelompok intervensi mengikuti organisasi sebanyak 21 orang $(70.1 \%)$, sedangkan pada kelompok kontrol sebanyak 26 orang $(87.7 \%)$ mengikuti organisasi.

\section{Distribusi Pengetahuan Responden Sebelum dan Sesudah Peer Education Metode Adolescent Friendly Pada Kelompok Intervensi Dan Kelompok Kontrol}

Tabel 2. Distribusi Pengetahuan Responden Sebelum dan Sesudah Peer Education Metode Adolescent Friendly Pada Kelompok Intervensi Dan Kelompok Kontrol

\begin{tabular}{llllllllll}
\hline \multirow{3}{*}{ No } & \multirow{3}{*}{ Kriteria } & \multicolumn{3}{c}{ Kelompok Intervensi } & \multicolumn{4}{c}{ Kelompok Kontrol } \\
\cline { 3 - 10 } & & \multicolumn{3}{c}{ Pengetahuan } & \multicolumn{3}{c}{ Pengetahuan } \\
\cline { 2 - 9 } & & Sebelum & \multicolumn{3}{c}{ Sesudah } & Sebelum & Sesudah \\
\cline { 2 - 9 } & f & $\%$ & F & $\%$ & f & $\%$ & F & $\%$ \\
\hline 1 & Baik & 6 & 20 & 28 & 93.3 & 5 & 16.7 & 3 & 10.0. \\
2 & Cukup & 18 & 60 & 2 & 6.7 & 10 & 33.3 & 20 & 66.7 \\
3 & Kurang & 6 & 0 & 0 & 0 & 15 & 50.0 & 7 & 23.3 \\
\hline
\end{tabular}

Tabel 5.2 menunjukkan bahwa pengetahuan responden kelompok intervensi sebelum diberikan peer education metode adolescent friendly sebagian besar mempunyai pengetahuan cukup (60\%), setelah diberikan intervensi berupa peer education dengan metode adolescent friendly pengetahuan responden mengalami perubahan yaitu sebagian besar pengetahuan responden berada pada kategori pengetahuan baik (93,3\%). Pengetahuan kelompok kontrol sebelum penelitian sebagian besar mempunyai pengetahuan kurang $(50.0 \%)$ dan setelah penelitian pengetahuan responden sebagian besar besar berada pada kategori pengetahuan cukup $(66,7 \%)$. 
3. Distribusi Sikap Responden Sebelum dan sesudah Intervensi pada Kelompok Intervensi dan Kelompok Kontrol

Tabel 3. Distribusi Sikap Responden Sebelum dan sesudah Intervensi pada Kelompok Intervensi dan Kelompok Kontrol

\begin{tabular}{cccccccccc}
\hline \multirow{2}{*}{ No } & \multirow{3}{*}{ Kriteria } & \multicolumn{3}{c}{ Kelompok Intervensi } & \multicolumn{4}{c}{ Kelompok Kontrol } \\
\cline { 3 - 10 } & & \multicolumn{3}{c}{ Sikap } & \multicolumn{4}{c}{ Sikap } \\
\cline { 2 - 10 } & & Sebelum & $\%$ & Sesudah & $\%$ & Sebelum & $\%$ & Setelah & $\%$ \\
\hline 1 & Positif & 17 & 51.5 & 17 & 51.5 & 16 & 48.5 & 19 & 57.6 \\
2 & Negatif & 13 & 39.4 & 13 & 39.4 & 14 & 45.5 & 11 & 33.3 \\
\hline
\end{tabular}

Tabel 3 menunjukkan bahwa sikap remaja kelompok intervensi sebelum dan sesudah diberikan peer education metode adolescent friendly sebagian besar mempunyai sikap positif yaitu sebesar $51.5 \%$, sedangkan pada kelompok kontrol sikap responden sebelum penelitian sebagian besar mempunyai sikap positif yaitu 57,6\%.

4. Hasil Analisis Perbedaan Pengetahuan dan Sikap Responden Sebelum dan Sesudah Intervensi pada Kelompok Intervensi dan Kelompok Kontrol

Tabel 4 Hasil Analisis Perbedaan Pengetahuan dan Sikap Responden Sebelum dan Sesudah Intervensi pada Kelompok Intervensi dan Kelompok Kontrol

\begin{tabular}{|c|c|c|c|c|c|}
\hline Kelompok & Variabel & $\mathbf{N}$ & Mean & SD & P Value \\
\hline \multirow[t]{8}{*}{ Intervensi } & Pengetahuan : & & & & \\
\hline & a. Sebelum & 30 & 13.40 & 2.358 & \multirow{3}{*}{$0.000 *$} \\
\hline & b. Sesudah & 30 & 17.53 & 1.592 & \\
\hline & Selisih & & 4.13 & & \\
\hline & \multicolumn{5}{|l|}{ Sikap : } \\
\hline & a. Sebelum & 30 & 63.57 & 3.510 & \multirow{3}{*}{$0.000 *$} \\
\hline & b. Sesudah & 30 & 66.27 & 2.852 & \\
\hline & Selisih & & 2.7 & & \\
\hline \multirow[t]{8}{*}{ Kontrol } & Pengetahuan : & & & & \\
\hline & a. Sebelum & 30 & 11.83 & 2.866 & \multirow{2}{*}{0.077} \\
\hline & b. Sesudah & 30 & 13.03 & 1.921 & \\
\hline & Selisih & & 1.2 & & \\
\hline & Sikap : & & & & \\
\hline & a. Sebelum & 30 & 56.13 & 6.356 & \multirow{3}{*}{$0.019 *$} \\
\hline & b. Sesudah & 30 & 58.00 & 5,83 & \\
\hline & Selisih & & 1,88 & & \\
\hline
\end{tabular}

Keterangan: * bermakna pada alpha $<0.05$

Hasil analisis pada tabel 5.4 terlihat bahwa rata-rata skor pengetahuan responden kelompok intervensi sebelum diberikan intervensi sebesar 13.40 dan rata-rata skor pengetahuan sesudah diberikan intervensi adalah 17.53. Terdapat perbedaan rata-rata skor pengetahuan sebesar 4.13. 
Berdasarkan hasil analisis lebih lanjut maka dapat disimpulkan bahwa ada perbedaan yang bermakna pengetahuan responden sesudah diberikan intervensi lebih baik dari sebelum diberikan intervensi pada kelompok intervensi ( $P$ value 0.000 , alpha $=0.05$ ).

Rata-rata skor sikap responden kelompok intervensi sebelum diberikan peer education sebesar 63.57 dan rata-rata skor sikap sesudah diberikan peer education adalah 66.27. Terdapat perbedaan rata-rata skor sikap sebesar 2.7. Berdasarkan hasil analisis lebih lanjut, maka dapat disimpulkan bahwa ada perbedaan yang bermakna sikap responden sesudah diberikan intervensi lebih baik dari sebelum diberikan intervensi pada kelompok intervensi ( $P$ value 0.000 , alpha= $0.000)$.

Hasil analisis pada kelompok kontrol terlihat bahwa rata-rata skor pengetahuan responden kelompok kontrol sebelum penelitian sebesar 11.83 dan rata-rata skor pengetahuan sesudah penelitian tanpa diberikan intervensi adalah 13.03. Terdapat perbedaan rata-rata skor pengetahuan sebesar 1.2. Berdasarkan hasil analisis lebih lanjut dapat disimpulkan bahwa tidak ada perbedaan yang bermakna pengetahuan responden yang tidak diberikan intervensi sebelum dan sesudah penelitian pada kelompok kontrol $(P$ value $=0.077$, alpha $=0.05)$.

Kondisi berbeda dari hasil analisis skor sikap pada kelompok kontrol. Rata-rata skor sikap responden kelompok kontrol sebelum penelitian sebesar 56.13 dan rata-rata skor sikap sesudah penelitian tanpa diberikan intervensi adalah 58.00. Perbedaan rata-rata skor sikap sebesar 1,88. Berdasarkan analisis lebih lanjut disimpulkan bahwa ada perbedaan yang bermakna sikap responden sesudah penelitian lebih baik dari sebelum penelitianensi pada kelompok kontrol $(P$ value $=0.019$, alpha $=0.05)$.

\section{Hasil Analisis Selisih Pengetahuan dan Sikap Responden Antara Kelompok Intervensi dan Kelompok Kontrol}

Tabel 5.5 Hasil Analisis Selisih Pengetahuan dan Sikap Responden Antara Kelompok Intervensi dan Kelompok Kontrol

\begin{tabular}{ccccc}
\hline Variabel & Kelompok & Mean & SD & P Value \\
\hline Pengetahuan & Intervensi & 17.53 & 1.592 & $0.000^{*}$ \\
& Kontrol & 13.03 & 1.921 & \\
\hline Sikap : & Intervensi & 66.27 & 2.852 & $0.000^{*}$ \\
& Kontrol & 58.00 & 5,83 & \\
\hline
\end{tabular}

Keterangan: * bermakna pada alpha $<0.05$ 
Hasil analisis dari tabel 5.5 tersebut, menggambarkan bahwa rata-rata total skor pengetahuan responden sesudah diberikan intervensi pada kelompok intervensi sebesar 17.53 dengan standar deviasi 1.592 dan rata-rata total skor pada kelompok kontrol yang tidak diberikan intervensi 13.03 dengan standar deviasi 1.921. Berdasarkan hasil analisis lebih lanjut maka disimpulkan bahwa terdapat perbedaan yang bermakna rata-rata skor pengetahuan responden sesudah diberikan edukasi sebaya antara kelompok intervensi dan kelompok kontrol yang tidak diberikan edukasi sebaya (Pvalue 0.000, alpha=0,05). Hasil analisis ini menunjukkan bahwa intervensi berupa Model Peer Education Metode Adolescent Friendly efektif untuk meningkatkan pengetahuan remaja.

Rata-rata total skor sikap responden sesudah diberikan intervensi pada kelompok intervensi sebesar 66.27 dengan standar deviasi 2.852 dan rata-rata skor pada kelompok kontrol yang tidak diberikan edukasi sebaya 58.00 dengan standar deviasi 5,83. Berdasarkan hasil analisis lebih lanjut, maka disimpulkan bahwa terdapat perbedaan yang bermakna rata-rata skor sikap responden sesudah diberikan intervensi antara kelompok intervensi dan kelompok kontrol yang tidak diberikan intervesi $(P$ value 0.000 , alpha $=0.05$ ). Hasil analisis ini menunjukkan bahwa Model Peer Education Metode Adolescent Friendly efektif untuk meningkatkan pengetahuan remaja.

\section{PEMBAHASAN}

\section{Perbedaan Pengetahuan Sebelum Dan Sesudah Diberikan Intervensi Pada Kelompok Intervensi dan Kelompok Kontrol}

Hasil analisis menunjukkan bahwa terdapat peningkatan rata-rata skor pengetahuan yang bermakna antara sebelum dan sesudah diberikan intervensi pada kelompok intervensi $(P$ value 0.000, alpha= 0.05). Hal ini sejalan dengan penelitian Ariani (2014) menyatakan bahwa peer education (pendidik sebaya) yang dilakukan dapat memberikan pengaruh terhadap peningkatan pengetahuan dan sikap siswa SMP tentang bahaya merokok. Secara substansi perbedaan tersebut sangat bermakna terhadap terjadinya perubahan perilaku seksual berisiko pada karena intervensi yang diberikan berupa Peer EducationMetode Adolescent Friendly. Hasil ini didukung oleh penelitian Ernawati (2000) pengetahuan responden tentang pencegahan anemia pada ibu hamil meningkat secara bermakna pada kelompok perlakuan yang mendapat penyuluhan dibanding kelompok kontrol.

Hasil penelitian lain dari Achjar (2006) juga menunjukkan adanya peningkatan pengetahuan kesehatan reproduksi yang diberikan melalui kelompok sebaya pada remaja di Kemiri Muka Depok. Pelaksanaan pendidikan melalui Peer Education Metode Adolescent Friendly yang dilakukan pada penelitian ini dilakukan sebanyak 3 kali dalam 3 minggu dengan menggunakan media buku modul dengan pendampingan peneliti yang berbeda-beda di setiap 
kelompok. Peer education (pendidik sebaya) merupakan sekelompok remaja yang nilainya dianut oleh remaja lain (Rice, 2015). Penerapan peer education dengan metode adolescent friendly merupakan pemberdayaan teman sebaya dalam memberikan pengetahuan, keterampilan, dan sikap positif kepada remaja.. Remaja terbuka dari pengaruh positif teman sebaya. Agar informasi kesehatan lebih diterima oleh remaja, maka harus melalui teman sebaya (UNESCO, 2006). Teman sebaya berperan memberikan pendidikan kesehatan kepada teman sebayanya untuk meningkatkan kesehatan secara efektif (Trunbull, 2010).

Edukasi sebaya merupakan salah satu pendekatan yang sering digunakan untuk mempengaruhi perubahan pengetahuan pada tingkatan kelompok (population Council 2000). Perubahan pengetahuan yang terjadi dipengaruhi oleh konten dan pembawa pesan. Pembawa pesan yang berasal dari kelompok itu sendiri memiliki pengaruh yang kuat dalam menarik perhatian kelompok. Jika pembawa pesan adalah orang dewasa akan dapat menimbulkan kesenjangan dalam penggunaan bahasa, istilah, dan gaya bicara yang dapat menghambat pemahaman arti pesan yang disampaikan serta menimbulkan kondisi belajar yang kurang interaktif. Kondisi ini juga ditunjukkan oleh hasil review riset dari Mellanby, Rees dan Tripp (2000) yang menyatakan bahwa pendidikan kesehatan yang dilakukan anak usia sekolah lebih efektif dilakukan melalui pemberdayaan kelompok sebaya, dibandingkan dengan pendidikan yang diarahkan oleh orang dewasa.

Penelitian ini telah mempertimbangkan karakteristik kelompok, pemilihan dan penyiapan edukator sebaya sebagai pembawa pesan secara tepat dan pemanfaatan edukator sebaya sebagai pemberi informasi dan pendukung bagi kelompok sebayanya, agar dapat memberikan pengaruh terhadap peningkatan pengetahuan, Kriteria sebagai syarat sebagai peer educator dalam adalah sebagai berikut: (1). Mahasiswa dengan prestasi akademik baik; (2) mampu berkomunikasi dengan baik.

Menurut peneliti, tingkat pendidikan formal sangat berperan penting dalam peningkatan pengetahuan seseorang terhadap sesuatu hal, dengan demikian pendidikan formal akan membantu meningkatkan pengetahuan pada remaja tentang perilaku seksual berisiko dengan didasari oleh pengetahuan yang dimilikinya. Pengetahuan yang baik salah satunya diperoleh dari pendidikan formal yang mendasari individu. Tingkat pendidikan responden pada penelitian ini sebagian besar berpendidikan tinggi untuk kelompok intervesi yaitu sebesar $50 \%$, sedangkan kelompok kontrol sebagian besar berpendidikan SMA yaitu sebesar 76, $66 \%$.

Hasil analisis pada kelompok kontrol menunjukkan bahwa tidak terdapat peningkatan rata-rata skor pengetahuan yang bermakna antara sebelum dan sesudah penelitian tanpa dilakukan intervensi pada kelompok ( $P$ value 0.000 , alpha $=0.019$ ). Tidak ada peningkatan rata-rata skor pengetahuan yang bermakna padan kelompok kontrol dipengaruhi oleh tidak adanya pemberian intervensi berupa edukasi sebaya 


\section{Perbedaan Sikap Sebelum Dan Sesudah Diberikan Intervensi Pada Kelompok Intervensi dan Kelompok Kontrol.}

Hasil analisis menunjukkan bahwa terdapat peningkatan rata-rata skor sikap yang bermakna antara sebelum dan sesudah diberikan intervensi pada kelompok intervensi ( $P$ value 0.000, alpha $=0.05$ ). Temuan ini sejalan dengan hasil penelitian Fitriani (2011) mengatakan terdapat peningkatan pengetahuan dan sikap yang bermakna sebelum dan sesudah diberikan edukasi sebaya pada kelompok intervensi.

Faktor yang mungkin mempengaruhi perubahan sikap responden pada kelompok intervesi adalah Pendidikan responden. Pendidikan formal sangat berperan penting dalam peningkatan pengetahuan seseorang terhadap sesuatu hal, dengan demikian pendidikan formal akan membantu meningkatkan sikap pada wanita usia subur dalam pencegahan anemia gizi besi dengan didasari oleh pengetahuan yang dimilikinya. Notoatmodjo (2010) juga mengatakan sikap yang baik dan langgeng bila didasari oleh pengetahuan yang baik pula. Pengetahuan yang baik tersebut salah satunya diperoleh dari pendidikan formal yang mendasari individu dalam bersikap.

Perubahan sikap yang terjadi dalam penelitian ini, diperoleh sebagai dampak perubahan pengetahuan remaja dari proses edukasi sebaya yang diperoleh. Proses edukasi sebaya yang dilakukan selama 3 minggu tersebut meningkatkan kontak atau interaksi yang terus menerus antar satu dan yang lainnya dalam anggota kelompok sebaya yang akhirnya mempengaruhi nilai remaja. Perubahan nilai yang terjadi berhubungan dengan perkembangan moral yang mulai memiliki keputusan untuk memiliki standar moral tersendiri dan mulai memahami justifikasi terhadap keputusan moral yang dilakukannya,

Kondisi berbeda dari hasil analisis skor sikap pada kelompok kontrol. Rata-rata skor sikap responden kelompok kontrol sebelum penelitian sebesar 56.18 dan rata-rata skor sikap sesudah penelitian tanpa diberikan edukasi sebaya adalah 58.00. Terdapat perbedaan rata-rata skor sikap sebesar 1.88. Berdasarkan analisis lebih lanjut disimpulkan bahwa ada perbedaan yang bermakna sikap responden yang tidak diberikan edukasi sebaya sebelum dan sesudah penelitian pada kelompok kontrol ( $P$ value 0.019 , alpha $=0.05)$.

\section{KESIMPULAN DAN SARAN}

Dari hasil penelitian dan pembahasan dapat disimpulkan bahwa terdapat peningkatan rata-rata skor pengetahuan, sikap, yang bermakna antara sebelum dan sesudah diberikan intervensi pada kelompok intervensi. Tidak terdapat peningkatan rata-rata skor pengetahuan yang bermakna sebelum dan sesudah diberikan edukasi sebaya antara kelompok kontrol. Terdapat peningkatan rata-rata skor sikap, yang bermakna sesudah diberikan edukasi sebaya antar kelompok kontrol.

Penelitian ini merekomendasikan kepada pelayanan kesehatan untuk mengembangkan kebijakan peer education metode adolencent friendly terintegratif dalam pelayanan kesehatan khususnya puskesmas untuk peningkatan kesehatan remaja di masyarakat. 


\section{DAFTAR PUSTAKA}

Allender, Judith A., Rector, Cherie, \& Warner, Kristine D., (2010), Community Health Nursing Promoting and Protecting The Public's Health, 7th Edition, Philadelphia ; Lippincott Williams \& Wilkins.

Anderson, E., \& Mc Farlane, J. (2004). Community As Partner:Theory and Practice in Nursing, $4^{\text {th }}$ edition. Philadelphia: Lippincott Williams \& Wilkins.

Anonim. (2005).Remaja dan Perilaku Seksual, Diakses darihttp://www.waspada.co.id. Pada tanggal 12 Januari 2007.

Depkes RI \& WHO.. (2000). Kesehatan Reproduksi Remaja (KRR), Buku Saku Untuk Remaja Usia 14-19 Tahun, Surabaya: Kanwil. Depkes. Propinsi Jawa Timur.

Dianawati, A., (2006). Pendidikan Seks Untuk Remaja, Jakarta: Kawan Pustaka.

Ervin, NF. (2002). Advanced community health nursing : Concept and practice. 5 th ed. Philadelphia : Lippincot.

Harahap., J., Lita., S.A. (2004). Pengaruh Peer Education Terhadap Pengetahuan Dan Sikap Mahasiswa Dalam Menanggulangi Hiv/Aids Di Universitas Sumatera Utara. Diakses dari http://www.usu.ac.id/digitallibraryrtl.htm diakses pada tanggal 25 Oktober 2007.

Hitchcock, J.E., Schubert, P.E., Thomas, S.A. (1999). Community health nursing: caring in action. Albani : Delmas Publisher.

Husni, F, 2005, Isu Kespro dalam Pilkada, www.suaramerdeka.com. Diakses pada tanggal 25 Oktober 2007.

Lembaga Demografi-FEUI, 2002, http://www.bkkbn.go.id, diperoleh tanggal 25 Oktober 2007.

Ma'shum, Y, 2006, Remaja dan Aspek Psikososial, www.harian-kompas.com. Missouri; Mosby Co.

Moeliono, L. (2003). Proses Belajar Aktif Kesehatan Reproduksi Remaja: Bahan Pegangan Untuk Memfasilitasi Kegiatan Belajar Aktif Untuk Anak \& Remaja Usia 10-14 Tahun. Jakarta: Perkumpulan Keluarga Berencana Indonesia (PKBI), Badan Koordinasi Keluarga Berencana Nasional (BKKBN), dan United Nations Population Fund (UNFPA).

Nina, C. A. 2007. Peran Sekolah Dalam Memberikan Pengetahuan Kesehatan Reproduksi Remaja Pada Siswa (Studi Kasus di SMAN 17 Surabaya Dan SMA Kemala Bhayangkari 1 Surabaya). Diakses dari http://www.adln.lib.unair.ac.id/ tanggal 12 September 2008.

Notoadmodjo, S. 1993. Pengantar Pendidikan Kesehatan dan Ilmu Perilaku Kesehatan. Yogyakarta : Andi Offset.

Pangkahila, W, 1997, Perilaku Seksual Remaja di Desa dan di Kota, Seminar Sehari, Fakultas Kedokteran, Universitas Indonesia.

Pathfinder International. (1998), Insight From Adolescent Project Experiences- 1992-1997. Galen, MA: Pathfinder.

Sabri,Luknis dan Hastono,S.P.(2006). Statistik Kesehatan.Edisi revisi, Jakarata; Rajawali Press.

Stanhope \& Lancaster, 2006 (). Community Health Nursing : Promoting Health Of Agregates, Families And Individuals, 4 th ed. St.Louis : Mosby, Inc.

Triswan, Y., (2007). Kesehatan Reproduksi Remaja: Membangun Perubahan Yang Bermakna, Out Look, 16(1), 1-8.

UNICEF. (2002). Working For and With Adolescent: Some UNICEF Examples. ADPU UNICEF. 